\title{
Inner Animalities
}





\section{g R O U N D W O R K S |}

ECOLOGICAL ISSUES IN PHILOSOPHY AND THEOLOGY

Forrest Clingerman and Brian Treanor, series editors

Series board:

Harvey Jacobs

Catherine Keller

Norman Wirzba

Richard Kearney

Mark Wallace

David Wood 



\title{
Inner Animalities
}

\author{
Theology and the End \\ of the Human
}

Eric Daryl Meyer

Fordham University Press $\quad$ New York 2018 
Fordham University Press gratefully acknowledges financial assistance and support provided for the publication of this book by Carroll College.

\section{Copyright (C) 2018 Fordham University Press}

All rights reserved. No part of this publication may be reproduced, stored in a retrieval system, or transmitted in any form or by any means-electronic, mechanical, photocopy, recording, or any other-except for brief quotations in printed reviews, without the prior permission of the publisher.

Fordham University Press has no responsibility for the persistence or accuracy of URLs for external or third-party Internet websites referred to in this publication and does not guarantee that any content on such websites is, or will remain, accurate or appropriate.

Fordham University Press also publishes its books in a variety of electronic formats. Some content that appears in print may not be available in electronic books.

Visit us online at www.fordhampress.com.

Library of Congress Cataloging-in-Publication Data available online at https://catalog.loc.gov.

Printed in the United States of America

$201918 \quad 54321$

First edition 
to Carolyn, Lupine, and Avery 
